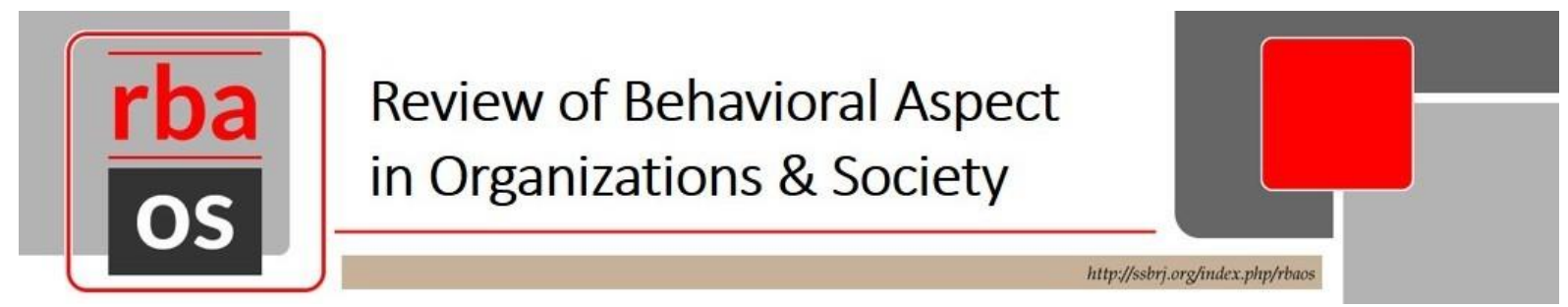

\title{
BEHAVIORAL INTENTION TOWARDS APPLICATION-BASED SHORT- DISTANCE DELIVERY SERVICES ADOPTION IN INDONESIA
}

\author{
Purnamaningsih, Universitas Multimedia Nusantara, Indonesia \\ Trihadi Pudiawan Erhan, Universitas Multimedia Nusantara, Indonesia \\ Nosica Rizkalla, Universitas Multimedia Nusantara, Indonesia
}

\begin{abstract}
Although online shop is small in scale, this type of business gives a significant impact for the economy. In order to support online shop to develop, improvement in delivery and logistic system is needed. One of the improvements in these aspects is the emergence of applicationbased short-distance delivery services. Unfortunately, these applications have not been widely adapted by the online shops in Indonesia. Thus, this study tries to explore what factors can influence online shops' decision to use these apps by implementing the unified theory of acceptance and use of technology (UTAUT). This study employed structural equation model to test the model and 5 hypotheses proposed, processed by Lisrel 8.8. The result shows that the ease of use aspect of the apps will only be relevant if it is deemed to be beneficial for the user. Moreover, the cognitive aspect also plays the role, as users tend to compare the acquired benefit with the cost incurred in using the app. As a conclusion, effort expectancy, performance expectancy and price value have a significant influence towards use behavior. On the other hand, social influence is not significantly influencing use behavior. Implications and limitations will also be discussed on this paper.
\end{abstract}

Keyword: performance expectancy, price value, social influence 


\section{Background of Research}

The internet user in Indonesia in 2017 has reached at about 143.26 people (APJII, 2017). With the large number of internet user, Indonesia is a potential market for the business development internet based such as online shop. The development of online shop in Indonesia is supported also by the improvement of platform e-marketplace that provides medium for small business to growth. The utilization of social media such as Instagram at approximately $87.13 \%$ (APJII, 2017) also force the growing of online shop in Indonesia.

The rapid growth of online is being enabled by Indonesian citizen's lifestyles that choose to buy product online at about $32.19 \%$ (APJII, 2017). Along with that statement, Indonesian digital business including online shop is predicted to give contribution at about $6 \%$ to Indonesia economy (Mutmainah, 2018).

Although it has great potential, online shop in Indonesia is still facing various obstacles. One of the obstacles they faced is an inadequate logistics system and high delivery costs (UNCTAD, 2017). In recent years to cope with this problem several solutions have been emerge by cultivating the development of internet. One of the most prominent solution is an of application-based short-distance delivery services.

Some of application-based short-distance delivery services are Go-Send (Gojek), Etobee, and Deliveree. The existence of this mobile application is a solution for online shop to have a reliable and affordable short distance of delivery service. Islam (2010) stated that mobile application is a series of programs that can be used to complete specific tasks through a mobile device. However, this technology has not been fully adopted by all online shop for various reasons such as the lack of standardization of the delivery process, the risk of loss and others. In order to survive these applications would need large number of consumers based due to the high cost of application development (Wang et al., 2006).

Therefore, successful strategy for mobile application developer to build a long-lived application should be based on an understanding of the factors influencing the use of mobile application (Wang et al., 2006). Several researches about user adoption technology have been carried out. Venkatesh et.al (2003) stated that the unified theory of acceptance model and use of technology (UTAUT) can thoroughly describes adaptation and usage of certain technology. Therefore, this research aims to examine the factors that influence the use of application-based short-distance delivery services by using the Unified Theory of Acceptance and Use of Technology (UTAUT) approach.

\section{Literature Review}

Davis et al (1989) stated that TAM (Technology Acceptance Model) can be used to identify the behavioral intention's person when they use a technology. This model has been used to analyze the ability of people to adopt technology. In this model, a person's behavioral intention of using technology is influenced by perceived ease of use, perceived usefulness, and also attitude toward using technology that is adopted from TRA (Theory of reaction action). Moreover, Venkatesh (2003) illustrated that it is better to measure behavioral intention using the unified theory of acceptance model and use of technology (UTAUT). There are four basic factors that influences behavioral intention and usage behavior toward technology, for instance effort expectancy, performance expectancy, social influence and facilitating condition. As the model progresses Venkatesh, et al (2012) then added habit, hedonic, motivation and price value as factors that influences personal behavioral intention by using technology that becomes 
UTAUT2. According to Venkatesh, et.al (2012) UTAUT2 model is better to illustrate behavioral intention through the use of technology.

Based on those explanation, this research uses UTAUT2 model to illustrate what factors that influence behavior intention uses application based short distance delivery service. The research model on this research as follows:

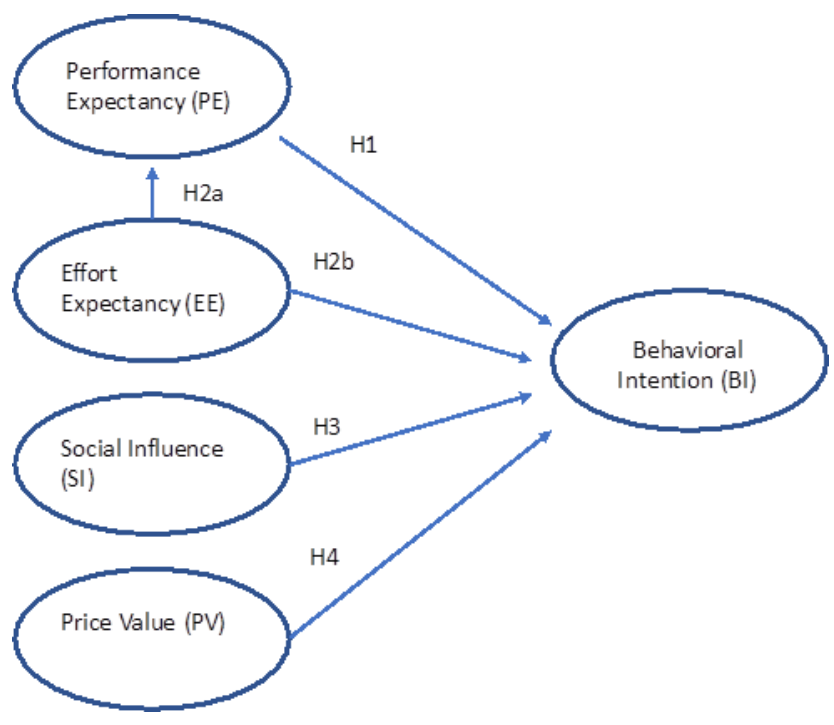

Figure 1. Research model

Although this research adopts UTAUT2 theory (Venkatesh, et.al, 2012) as it's based model there are several variables that were excluded in this research. Facilitating condition that adopts consumer's perception about additional factor that can be used to utilize technology (Venkatesh, et.al, 2012), habit and hedonic motivation are happiness to use technology (Ventakesh, 2012) are not included in research model. This research is conducted by the time internet in Indonesia has intensely developed, so the utilization of technology has become life style. Facility in using technology is not an obstacle again of using technology. Meanwhile, aspect of pleasure by using application is not included considering that application based short distance delivery services does not contain elements of entertainment to describe hedonic motivation variable.

\section{Mobile Application}

Regarding to the resent technology development of people's life cannot be separated from the use of mobile applications. Each user utilizes mobile applications in their life everyday such as entertainment through games, interaction with friends through instant messaging and many other activities includes browsing internet. The use of this mobile application is not only limited to daily needs but also towards business activities. Merrick (2016) classifies the applications into 7 categories. There are utilities apps is designed to help for completing simple tasks such as calculators and communication; entertainment apps is an application that includes entertainment such as dubsmash; games apps is an application that allows users to play games; news apps is an application for sharing information; productivity apps is an application which is designed to facilitate work; lifestyle apps is an application which is designed to support life styles such as fitness apps and social networking apps are applications that are designed so those users can be easily to connect with others. 


\section{Behavioral Intention (BI)}

$\mathrm{Wu} \&$ Wang (2005) stated that behavioral intention is a continuance action such as using technology in the long term. Whereas Zeithmal et al. (1996) described that behavioral intention as an intention to reusing, positive word of mouth, and the desire to recommend others. Therefore, behavioral intention can be described as a set of behaviors whether it is to express positive things, recommending, long term usage, higher usage frequency, or willingness to pay premium price that would be manifested depending on the the ability of service providers (application) to give satisfaction.

\section{Performance Expectancy (PE)}

Davis (1989) stated that usefulness has the same meaning with performance expectancy. Performance Expectancy or usefulness in this research is defines as individual beliefs that by using a certain technology, their performance can improve (Venkatesh, et.al, 2012). Mobile applications can provide benefits to users in various ways, such as applications developed to help performing a task quicker, therefore an objective can be easily achieved. If application can perform well this than can increase the user's willingness to use it for a long term period. Several researches have confirmed the positive effect of performance expectation on behavioral intention including Hew et.al (2015), Wei et.al (2009) and Bhatiasevi (2016) and also Venkatesh et. al (2003). Therefore, the hypothesis proposes in this research are:

\section{$\mathrm{H}_{1}$ : Performance Expectancy has a positive influence on Behavioral Intention.}

\section{Effort Expectancy (EE)}

Effort Expectancy is an ease feels by consumers when they use technology (Venkatesth, et.al, 2012). Most application available on the market today are designed to give the users an utmost convenience when using it including an easy navigation and attractive user interface that will allow user to have a steep learning curve. Those conveniences that are being offered will encourage users to become a long time user. This statement is also supported also by research conducted by Hew et al (2015), Venkatesh et, al (2012), Wei et.al (2009) and Bhatiasevi (2016) who said that effort expectancy is a factor that determines behavioral intention on technology adoption. In addition, according to Akturan \& Tezcan et.al, (2012) and Wang et al. (2008) the ease of using the application will encourage users to feel the benefits of the application. This is in line with Davis (1989) who claimed that effort expectancy is mediated by performance expectancy in influencing behavioral intention. Therefore, the hypothesis proposed in this research:

$\mathrm{H}_{2 \mathrm{a}}$ : Effort Expectancy has a positive influence on Behavioral Intention

$\mathrm{H}_{2 \mathrm{~b}}$ : Effort Expectancy has a positive influence on Performance Expectancy

\section{Social influence}

Fishbaen and Ajezn, (1975) firstly introduced subjective norms as social influences which are factors that can influence behavioral intention of technology adoption. Social influence can be defined as the perception of someone who considers suggestions of people around them to be important at deciding the technology to use (Venkatesh et.al, 2003). How sure someone to use the technology is greatly influenced by the suggestions of people around them. Therefore, for them technology adoption can be done faster because they have already get reference to support that decision from people around them. Social influence can also influence a person to adopt certain behaviors related to the use of technology although it is something they do not like. Several researches related to social influence have been carried out by Bashir and Madhaviah 
(2015), Bhatiasevi (2016) and Venkatesh and Davis (2000) who stated that social influence has an influence on behavioral intention. Therefore, the hypothesis is proposed in this research:

$\mathrm{H}_{3}$ : Social Influence has a positive influence on Behavioral Intention.

Price Value (PV)

Price Value is a process on the cognitive domain of consumers of comparing the benefits that is provided by an application with the financial cost that they would bear to use the application (Venkatesh, 2012). Application users will still consider the financial amount incurred when they use the application. If the benefits are greater than financial sacrifice, the user will use the application for a long term. This is in line with the research from Hew et al. (2015) who described that price value has an influence on behavioral intention. Therefore, the hypothesis is proposed in this research:

$\mathrm{H}_{4}$ : Price Value has a positive influence on Behavioral Intention

\section{Methods of Research}

Research Design and Sample

This research uses descriptive research to find out the influence between variables in this research. Respondents in this research are online shops in Indonesia who has known how to operate application-based short-distance delivery services. The number of samples uses in this research is 133 online shop. This research uses nonprobability sampling with a judgmental sampling technique.

\section{Measurement and data collection}

The indicators use in this research refers to several previous research. The questionnaire in this research uses Indonesia and it is distributed online to online shops who have met the criteria. The distribution of online questionnaires is done considering that respondents in this research do not exactly have physical retail, therefore it was not possible to access directly, so online approach would be more appropriate. Each respondent has to answer all statement indicators through a likert scale 1-7, with number 1 indicates strongly disagree and number 7 shows strongly agree with the statement on the questionnaire.

Table 1. Construct Sources

\begin{tabular}{lcl}
\hline Construct & $\begin{array}{c}\text { Number } \\
\text { of Items }\end{array}$ & \multicolumn{1}{c}{ Sources } \\
\hline Behavioral Intention & 3 & $\begin{array}{l}\text { Venkatesh } \text { et al. (2012), Namkung and Jang } \\
(2007)\end{array}$ \\
Performance Expectancy & 3 & $\begin{array}{l}\text { Venkatesh } \text { et al. (2003), Venkatesh } \text { et al. (2012) } \\
\text { Effort Expectancy }\end{array}$ \\
Social Influence & 3 & Venkatesh et al. (2003), Venkatesh et al. (2012) \\
Price Value & 3 & Wei et al. (2009) \\
\hline
\end{tabular}

\section{Data analysis}

To achieve this research objectives, the data will be analyzed by using Structural Equation Modeling (SEM) with Lisrel 8.8. The data analysis method on SEM is done through two stages, this refers to the stages in Hair et al (2010), the first step is to analyze confirmatory factor analysis (CFA) to evaluate the validity and reliability of the measurement model. If the data in the first stage produces conclude that the measurements are valid and reliable, then the second 
step can be done, namely doing a structural analysis of the model to see the effect between variables.

\section{Results and Discussion}

Respondent's Profile

Table 2 shows the characteristics of respondents in this research, $43.1 \%$ are on the age between $17-22$, mostly is a fashion related business at about $35.3 \%$, and the majority of them lived outside Jakarta around 77\%. Most of them uses Go-Send application (72.3\%) and they use applications on the basis advertising $(43.1 \%)$.

Table 2. Statistics Descriptive

\begin{tabular}{|c|c|c|}
\hline & & Persentase $(\%)$ \\
\hline \multirow[t]{5}{*}{ Age } & $17-22$ & $43.1 \%$ \\
\hline & $23-28$ & $37.7 \%$ \\
\hline & $29-34$ & $10.8 \%$ \\
\hline & $35-40$ & $6.9 \%$ \\
\hline & Above 40 years' old & $1.5 \%$ \\
\hline \multirow[t]{12}{*}{ Products to sell } & Fashion & $35.3 \%$ \\
\hline & Household & $2.3 \%$ \\
\hline & Office stationery & $1.5 \%$ \\
\hline & Furniture & $1.5 \%$ \\
\hline & Make up & $11.5 \%$ \\
\hline & Health Product & $1.5 \%$ \\
\hline & Baby and toddler's product & $2.3 \%$ \\
\hline & Automotive & $3.1 \%$ \\
\hline & Sport product & $1.5 \%$ \\
\hline & Trinkets & $20 \%$ \\
\hline & $\begin{array}{l}\text { Gadget, computer and } \\
\text { electronic }\end{array}$ & $3.1 \%$ \\
\hline & Food & $31.4 \%$ \\
\hline \multirow{4}{*}{$\begin{array}{l}\text { Application-based short- } \\
\text { distance delivery services } \\
\text { are used }\end{array}$} & Go send & $72.3 \%$ \\
\hline & Grab Express & $24.6 \%$ \\
\hline & Ninja Express & $0.7 \%$ \\
\hline & Others & $3 \%$ \\
\hline \multirow{6}{*}{$\begin{array}{l}\text { Information about } \\
\text { application }\end{array}$} & Friend & $41.5 \%$ \\
\hline & Family & $13.1 \%$ \\
\hline & Colleague & $23.1 \%$ \\
\hline & Others Online shop & $35.3 \%$ \\
\hline & Advertisement & $43.1 \%$ \\
\hline & Others & $6.2 \%$ \\
\hline \multirow[t]{2}{*}{ Domicile } & Jakarta & $23 \%$ \\
\hline & Outside Jakarta & $77 \%$ \\
\hline
\end{tabular}

\section{Validity and Reliability}

Table 3 shows that the value of Construct Reliability (CR) and Variance Extracted (VE) of the measurements used in this research are above 0.5 and 0.7 . It indicates that all measurements are reliable. The result of validity testing in this research shows that the value of factor loading each indicator above 0.5 and T-value above 1.96 means that all measurements are valid 
Table 3. Validity and Reliability

\begin{tabular}{cccccc}
\hline Variable & Indicator & T-Value & $\begin{array}{c}\text { Standardized } \\
\text { Loading } \\
\text { Factor }\end{array}$ & $\begin{array}{c}\text { Construct } \\
\text { Reliability } \\
\text { (CR) }\end{array}$ & $\begin{array}{c}\text { Average } \\
\text { Variance } \\
\text { Extract } \\
\text { (AVE) }\end{array}$ \\
\hline $\begin{array}{c}\text { Performance } \\
\text { Expectancy }\end{array}$ & PE1 & 12.47 & 0.89 & & \\
& PE2 & 13.04 & 0.92 & 0.9 & 0.70 \\
\hline \multirow{2}{*}{ Effort } & EE1 & 8.54 & 0.68 & & \\
Expectancy & EE2 & 14.83 & 0.74 & & \\
& EE3 & 14.83 & 0.95 & 0.96 & 0.82 \\
& EE4 & 14.43 & 0.95 & & \\
Social & SC1 & 8.59 & 0.75 & & \\
Influence & SC2 & 8.32 & 0.72 & 0.78 & 0.54 \\
& SC3 & 8.55 & 0.74 & & \\
\hline \multirow{2}{*}{$\begin{array}{c}\text { Price Value } \\
\text { PV1 }\end{array}$} & PV2 & 10.70 & 0.81 & & \\
& PV3 & 12.44 & 0.9 & 0.88 & 0.72 \\
Behavioral & BI1 & 11.26 & 0.84 & & \\
Intention & B12 & 12.39 & 0.89 & & \\
\hline
\end{tabular}

\section{Hypothesis Testing and Model Fit}

The result from all overall fit measure from structural equation model on table 4 shows that there is conformity between data and the research model that is represents by the result of RMSEA at 0.079 , CFI at 0.95 , and PNFI at 0.71 .

Table 4. Model Fit Indices for the Overall Model

\begin{tabular}{|lll|}
\hline Index & Value & $\begin{array}{l}\text { Cutoff Value for GOF } \\
\text { Index }\end{array}$ \\
\hline RMSEA & 0.079 & RMSEA $<0.08$ \\
CFI & 0.95 & CFI $\geq 0.95$ \\
PNFI & 0.71 & $0 \leq$ NFI $\leq 1$ \\
\hline
\end{tabular}

The hypothesis result in this research is shows on picture 2. The t-value of $\mathrm{H} 1$ (3.56), $\mathrm{H} 2 \mathrm{~b}$ (7.10), and $\mathrm{H} 4$ (2.20) are above the critical value of 1.96 it indicates that $\mathrm{H} 1, \mathrm{H} 2 \mathrm{~b}, \mathrm{H} 3$ are supported by the data. Meanwhile, H2a and $\mathrm{H} 3$ hypothesis has t-value $(0.38)$ and $(0.38)$ which are under the critical value it means that the gathered data does not support those hypotheses. 


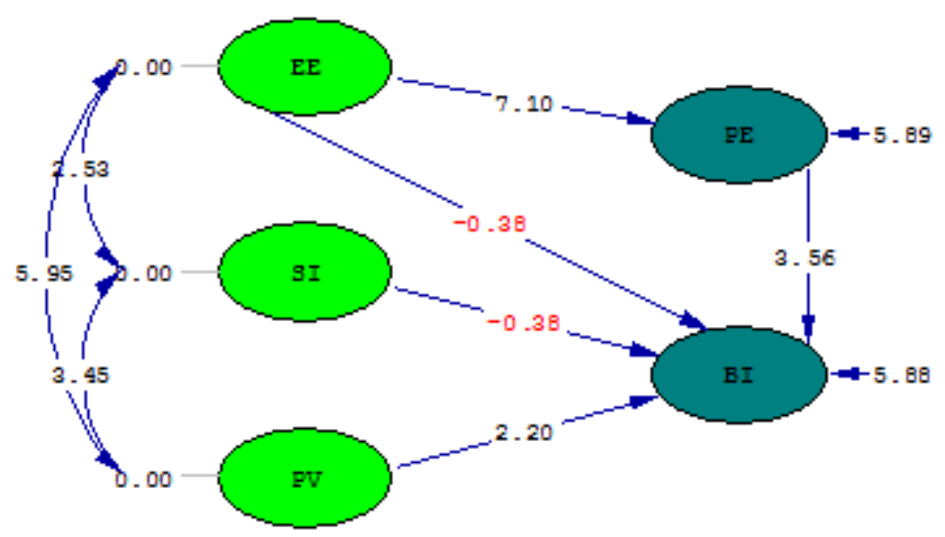

Figure 2. The Structural Model

\section{Discussion and research limitation}

\section{Discussion}

This research explains that there is a positive influence between performance expectancy and behavioral intention. The results of this research are in line with the findings of Venkatesh et. al (2003), Hew et.al (2015), Wei et.al (2009) and Bhatiasevi (2016). This shows that online shops in Indonesia in regard to application are still prioritizing the benefits of a technology specifically whether the application can abridge processing time. Therefore, the mobile application developer must be able to make an application that would significantly simplify their business process.

In this research the effort expectancy also has an influence on behavioral intention through performance expectancy variables, this is in line with Wang et.al (2008) Davis (1989). It means that every benefit provided by the application must come with the simplicity in its operation. The simplicity of operation an application both its user interface or user experience can increase user's retention. For this reason, mobile application developers can design features which make easier to involve users for design process.

Price Value also has a positive influence on behavioral intention. This is in line with the research by Hew et al (2015) even though users feel the benefits of a technology, but the cognitive aspect remains as factor to consider. The question of "How much is cost? and "What are the benefit?" are a constant process especially when it comes to business. Mobile application developers then must be able to offer competitive prices in order to be able to increase the desire from users. Application users might be willing to spend more if they feel benefits are worth it.

Social Influence does not have an influence on behavioral intention. These findings are not in line with (Venkatesh, 2000) but in line with Hew et al (2015) and Davis (1989). It is allegedly due to the nature of respondent itself. In this research the respondent are businesses. Like most business, a logical factor such as benefit, time, and cost would be a driver the adoption of a technology because it matters to the bottom line. Meanwhile, social influence main driving forces are peer pressure that would not be a factor affecting a business bottom line.

\section{Limitations and Future Research}

Not all application included in this research are specifically designed to be a short distance package delivery application. Therefore, it is possible that the respondent view of these 
applications are bias by its other usage. So, for next research may use a specific application only delivery service.

\section{Acknowledgements}

The author would like to thank to Diretorat Riset dan Pengabdian Masyarakat. Direktorat Jendral Penguatan Riset dan Pengembangan dan Kementrian Riset, Teknologi, dan Pendidikan Tinggi according to Research Contract Number: 587/LPPM-UMN/II/2018, on Feb, $1^{\text {st }} 2018$ that has given financial support in this research.

\section{References}

A. P. J. I. (2017). Penetration infographics and behavior of Indonesian internet users. ID: APJII (translated from Indonesian: Infografis Penetrasi \& Perilaku Pengguna Internet Indonesia: Survey 2017)

Akturan, U., \& Tezcan, N. (2012). Mobile banking adoption of the youth market: Perceptions and intentions. Marketing Intelligence \& Planning, 30(4), 444-459.

Bashir, I., \& Madhavaiah, C. (2015). Consumer attitude and behavioural intention towards Internet banking adoption in India. Journal of Indian Business Research, 7(1), 67-102.

Bhatiasevi, V. (2016). An extended UTAUT model to explain the adoption of mobile banking. Information Development, 32(4), 799-814.

Davis, F. D. (1989). Perceived usefulness, perceived ease of use, and user acceptance of information technology. MIS quarterly, 13(3), 319-340.

Hair, J. F., Black, W. C., Babin, B. J., Anderson, R. E., \& Tatham, R. L. (2010). Multivariate data analysis (6th). New Jersey: Pearson Education, Inc.

Hew, J. J., Lee, V. H., Ooi, K. B., \& Wei, J. (2015). What catalyses mobile apps usage intention: an empirical analysis. Industrial Management \& Data Systems, 115(7), 12691291.

Islam, R., Islam, R., \& Mazumder, T. (2010). Mobile application and its global impact. International Journal of Engineering \& Technology (IJEST), 10(6), 72-78.

Merrick, L. (2016, March 21). Different type of apps that app developer need to know about. Buzinga. Retrieved from http://www.buzinga.com.au/buzz/how-many-app-types-arethere/

Muthmainah, D. A. (2018, February 21). Kontribusi Ekonomi Digital Masih Mini, Cuman Enam Persen. CNN Indonesia. Retrieved from https://www.cnnindonesia.com/ekonomi/ 20180221152412-532-277766/kontribusi-ekonomi-digital-masih-mini-cuma-enampersen

Tsu Wei, T., Marthandan, G., Yee-Loong Chong, A., Ooi, K. B., \& Arumugam, S. (2009). What drives Malaysian m-commerce adoption? An empirical analysis. Industrial Management \& Data Systems, 109(3), 370-388.

UNCTAD. 2017. Using Trade Policy to Drive Value Addition: Lessons from Indonesia's Ban on Nickel Exports. Geneva.

United Nations Conference on Trade and Development. (2017). Using trade policy to drive value addition: Lessons from Indonesia's ban on nickel exports (Background document to the Commodities and Development Report 2017). Retrieved from https://unctad.org/en/PublicationsLibrary/suc2017d8_en.pdf

Venkatesh, V., \& Davis, F. D. (2000). A theoretical extension of the technology acceptance model: Four longitudinal field studies. Management science, 46(2), 186-204.

Venkatesh, V., Morris, M. G., Davis, G. B., \& Davis, F. D. (2003). User acceptance of information technology: Toward a unified view. MIS quarterly, 27(3), 425-478.

Venkatesh, V., Thong, J. Y., \& Xu, X. (2012). MIS quarterly. MIS quarterly, 36(1), 157-178. 
Wang, Y. S., Lin, H. H., \& Luarn, P. (2006). Predicting consumer intention to use mobile service. Information systems journal, 16(2), 157-179.

Wu, J. H., \& Wang, S. C. (2005). What drives mobile commerce?: An empirical evaluation of the revised technology acceptance model. Information \& management, 42(5), 719-729. 